\title{
KARAKTERISTIK SENSORIS DAN KIMIA PADA ABON NANGKA MUDA (Artocarpus heterophyllus LMK) DENGAN PENAMBAHAN TEMPE
}

\author{
Ulfa Qurrota A'yuni Nur Jannah, Darimiyya Hidayati, Abdul Aziz Jakfar \\ Jurusan Teknologi Industri Pertanian, Fakultas Pertanian, Universitas Trunojoyo Madura \\ Korespondensi : Jl. Raya Telang PO BOX 2 Kamal-Bangkalan, E-mail : Ulfaayuni49@gmail.com
}

\begin{abstract}
Unripe jackfruit is one vegetables that is usually processed into Indonesian dishs. Beside unripe jackfruit processed into vegetables can also be developed and processed into a dry product called beef floss. Unripe jackfruit has a very low protein content, so it needs other raw material to improve protein content of the floss we added tempeh to the floss = gembus tempeh or soybean tempeh, as much as 15\%, 25\%,35\% and 0\% as control. This study uses a Completely Randomized Design (CRD) with 2 factors. The first factor is proportion of unripe jackfruit and tempeh, and the second factor is type of tempeh. Parameter of this research are organoleptic evaluation, the color, moisture content and protein content. The result of organoleptic evaluation is the proportion $25 \%$ soybean tempeh prefered for aroma, taste, color, texture. The highest L (Lightness) was resulted from 35\% soybean tempeh. The highest moisture content was shown by floss with 15\% soybean tempeh. Protein content increased from 4,3775\% to $39,3975 \%$ by addition of soybean tempeh while protein increased from $4,3775 \%$ to $14,8835 \%$ in beef floss added with gembus tempeh.
\end{abstract}

Keywords : unripe jackfruit, beef floss, protein content

\section{PENDAHULUAN}

Nangka muda merupakan salah satu sayuran yang banyak tumbuh di Indonesia dan relatif diolah menjadi sayur lodeh, sayur gudeg dan lain sebagainya. Nangka muda selain sebagai sayuran juga dapat diolah dan dikembangkan menjadi sebuah produk olahan yang praktis dan tahan lama salah satunya adalah abon. Abon merupakan lauk pauk yang banyak digemari oleh masyarakat, karena praktis dan awet serta dapat dikonsumsi setiap saat.

Tabel 1. Komposisi Gizi Per 100 gram Nangka Muda

\begin{tabular}{cc}
\hline Komponen Gizi & Nangka Muda \\
\hline Protein $(\mathrm{g})$ & $2,0 \%$ \\
Lemak $(\mathrm{g})$ & $0,4 \%$ \\
Karbohidrat $(\mathrm{g})$ & $11,3 \%$ \\
Air $(\mathrm{g})$ & $85,4 \%$ \\
\hline
\end{tabular}

Sumber: Direktorat gizi, Depkes (2009) dalam Anggorowati (2012)

Kandungan protein nangka muda adalah 2,0\% dalam 100 gram nangka muda, sedangkan menurut standar mutu abon kandungan protein pada abon standarnya adalah $15 \%$ kandungan protein. Menurut Anggorowati (2012) kandungan protein pada abon nangka muda dapat meningkat $24,514 \%$ dengan penambahan ragi tempe pada saat fermentasi. Pada penelitian ini untuk meningkatkan kandungan protein abon nangka muda dengan cara menambahkan tempe. Tempe merupakan produk olahan yang berbahan dasar dari kedelai yang telah diproses dan diberi bahan tambahan ragi dan difermentasi sehingga membentuk tempe. Dengan penambahan tempe ini diharapkan kandungan protein abon nangka muda dapat mengalami peningkatan.

\section{METODE PENELITIAN}

\section{Alat} penelitian ini diantaranya: pisau, panci, kompor, wajan, sutil, ember kecil, saringan, sendok dan cobek 


\section{Bahan}

Bahan-bahan yang digunakan dalam penelitian ini adalah: Nangka muda, tempe, rempah-rempah, garam, gula dan minyak

\section{Proses pembuatan abon nangka muda}

Nangka muda dan tempe dilakukan pemotongan dengan ketebalan $2 \mathrm{~cm}$, kemudian dilakukan perebusan dan berlanjut ke penirisan. Setelah ditiriskan nangka muda dan tempe dihaluskan, kemudian penumbukan bumbu dan penggorengan bumbu, selanjutnya bumbu dicampur dengan nangka muda dan tempe yang telah dihaluskan, kemudian digoreng hingga masak, selanjutnya di pres minyaknya dengan menggunakan alat spinner.

\section{Parameter pengujian}

Uji organoleptik, uji warna menggunakan color reader, penentuan nilai hue, uji kadar air dan uji protein.

\section{Desain Penelitian}

Rancangan percobaan menggunakan Rancangan Acak Lengkap (RAL) dengan dua perlakuan dua kali ulangan yaitu :

1. Perlakuan jenis tempe yaitu tempe kedelai dan tempe gembos

2. Perlakuan proporsi tempe dengan nangka muda

Tabel 2.Desain Penelitian

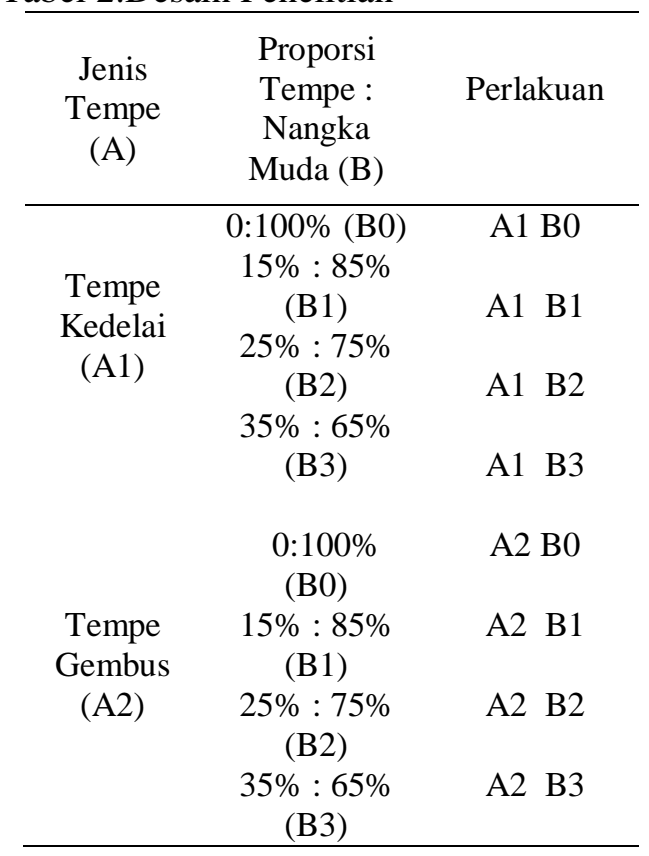

Analisis Data

Data dianalisis variansi (ANOVA) menggunakan software Statistical Product and Service Solution (SPSS) 16.0. untuk mengetahui adanya pengaruh signifikan ( $\mathrm{p} \leq$ $0,05)$ pada perlakuan nangka muda dan tempe.

\section{HASIL DAN PEMBAHASAN}

\section{UJI ORGANOLEPTIK TINGKAT KESUKAAN WARNA}

Tabel 3. Pengaruh Jenis Tempe terhadap kesukaan warna

\begin{tabular}{cc}
\hline Jenis Tempe & $\begin{array}{c}\text { Kesukaan } \\
\text { Warna }\end{array}$ \\
\hline Tempe Gembos & $4,279^{\mathrm{a}}$ \\
Tempe Kedelai & $4,704^{\mathrm{b}}$ \\
\hline
\end{tabular}

Ket : Angka yang ditulis dengan huruf yang sama berarti tidak berbeda nyata

Nilai kesukaan tertinggi terhadap warna adalah dengan adanya perlakuan penambahan tempe kedelai dengan nilai 4,704, sedangkan nilai kesukaan terendah pada abon nangka muda adalah dengan perlakuan penambahan jenis tempe yaitu dengan penambahan tempe gembos dengan nilai 4,279. Menurut Aminah (2000) semakin banyak penambahan tepung tempe maka warna yang dihasilkan semakin coklat. Warna coklat tersebut disebabkan oleh reaksi pencoklatan non enzimatis atau reaksi maillard yang terjadi karena adanya reaksi antara gula pereduksi dengan gugus amino bebas dan asam amino atau protein.

Tabel 4. Pengaruh proporsi terhadap kesukaan warna

\begin{tabular}{cc}
\hline $\begin{array}{c}\text { Proporsi tempe : } \\
\text { Nangka muda }\end{array}$ & Kesukaan pada warna \\
\hline $15 \%: 85 \%$ & $4,04^{\mathrm{a}}$ \\
$25 \%: 75 \%$ & $4,36^{\mathrm{a}}$ \\
$35 \%: 65 \%$ & $4,82^{\mathrm{b}}$ \\
$0: 100 \%$ & $4,75^{\mathrm{b}}$ \\
\hline Ket : Angka yang ditulis dengan huruf yang sama \\
berarti tidak berbeda nyata \\
\multicolumn{2}{c}{ Pada hasil kesukaan warna abon } \\
nangka muda dengan semakin banyak \\
proporsi tempe yang ditambahkan maka \\
warna yang dihasikan juga semakin banyak \\
disukai. Hal ini sejalan dengan penelitian \\
(Aida et al. 2014) yang menyatakan bahwa \\
semakin banyak proporsi ikan layang yang \\
ditambahkan pada abon jantung pisang warna
\end{tabular}


yang dihasilkan juga lebih banyak disukai oleh panelis dengan warna coklat keemasan.

Uji organoleptik tingkat kesukaan rasa

Tabel 5. Pengaruh Jenis Tempe terhadap rasa

\begin{tabular}{cc}
\hline Jenis Tempe & Kesukaan rasa \\
\hline Tempe Gembos & $3,496^{\mathrm{a}}$ \\
Tempe Kedelai & $3,717^{\mathrm{b}}$ \\
\hline
\end{tabular}

Ket : Angka yang ditulis dengan huruf yang sama berarti tidak berbeda nyata

Rasa abon nangka muda dengan adanya penambahan jenis tempe gembus memperoleh hasil 3,496 yang menunjukkan sangat berbeda nyata dengan abon nangka muda dengan adanya penambahan jenis tempe kedelai dengan skor 3,717. Hal ini menunjukkan bahwa panelis lebih banyak menyukai rasa abon nangka muda dengan adanya penambahan jenis tempe kedelai dibandingkan rasa pada abon nangka muda dengan adanya penambahan jenis tempe gembus. Hal ini sejalan dengan peneitian Manurung (2009) bahwa semakin banyak penambahan tempe ampas tahu pada pembuatan cookies dapat memberikan rasa asing yang semakin tinggi juga, sehingga menyebabkan paneis tidak banyak menyukai cookies dengan adanya penambahan tempe ampas tahu.

Tabel 6. Pengaruh proporsi terhadap kesukaan rasa

\begin{tabular}{cc}
\hline $\begin{array}{c}\text { Proporsi tempe : } \\
\text { Nangka muda }\end{array}$ & $\begin{array}{c}\text { Kesukaan pada } \\
\text { rasa }\end{array}$ \\
\hline $15 \%: 85 \%$ & $3,24^{\mathrm{a}}$ \\
$25 \%: 75 \%$ & $3,52^{\mathrm{a}}$ \\
$35 \%: 65 \%$ & $3,66^{\mathrm{ab}}$ \\
$0: 100 \%$ & $4,00^{\mathrm{b}}$ \\
\hline
\end{tabular}

Ket : Angka yang ditulis dengan huruf yang sama berarti tidak berbeda nyata

Nilai tertinggi adalah pada abon nangka muda dengan proporsi $100 \%$ nangka muda tanpa adanya perlakuan dengan skor 4,00 yang menunjukkan banyak disukai oleh panelis. Menurut Koswara (2009) rasa dan bau langu merupakan salah satu masalah dalam pengolahan kedelai, karena adanya enzim lipoksidase pada kedelai. Hal ini terjadi karena enzim lipoksidase menghidrolisis atau menguraikan lemak kedelai menjadi senyawa - senyawa penyebab bau langu yang tergolong pada kelompok heksanal dan heksanol. Senyawa - senyawa tersebut dalam konsentrasi rendah sudah dapat menyebabkan rasa dan bau langu.

\section{Uji organoleptik tingkat kesukaan tekstur}

Tabel 7. Pengaruh Jenis Tempe terhadap tekstur

\begin{tabular}{cc}
\hline Jenis Tempe & Kesukaan tekstur \\
\hline Tempe Gembos & $4,133^{\mathrm{a}}$ \\
Tempe Kedelai & $4,400^{\mathrm{b}}$ \\
\hline
\end{tabular}

Ket : Angka yang ditulis dengan huruf yang sama berarti tidak berbeda nyata

Nilai kesukaan tertinggi terhadap tekstur adalah dengan adanya perlakuan penambahan tempe kedelai dengan nilai 4,400, sedangkan nilai kesukaan terendah pada abon nangka muda adalah dengan perlakuan penambahan jenis tempe yaitu dengan penambahan tempe gembos dengan nilai 4,133. Menurut Golberg dan Williams (1991) dalam Manurung (2009) menyatakan bahwa dengan adanya penambahan tempe ampas tahu dalam pembuatan cookies maka tekstur yang dihasilkan juga semakin tidak lembut dan tidak keras, sehingga cookies yang dihasilkan akan memiliki tingkat kerenyahan yang lebih rendah, karena adanya serat yang banyak terkandung dalam tempe ampas tahu tersebut.

Tabel 8.Pengaruh proporsi terhadap kesukaan tekstur

\begin{tabular}{cc}
\hline Proporsi tempe & $\begin{array}{c}\text { Kesukaan pada } \\
\text { : Nangka muda }\end{array}$ \\
\hline $15 \%: 85 \%$ & $3,97^{\mathrm{a}}$ \\
$25 \%: 75 \%$ & $4,33^{\mathrm{b}}$ \\
$35 \%: 65 \%$ & $4,32^{\mathrm{b}}$ \\
$0: 100 \%$ & $4,43^{\mathrm{b}}$ \\
\hline
\end{tabular}

Ket : Angka yang ditulis dengan huruf yang sama berarti tidak berbeda nyata

Penambahan tempe pada abon nangka muda dengan semakin tinggi proporsi yang digunakan maka semakin bagus juga tekstur yang dihasilkan. Proporsi tempe 25\% dan $35 \%$ menunjukkan tidak berbeda nyata dengan abon nangka muda tanpa adanya penambahan tempe, tetapi berbeda nyata dengan proporsi penambahan tempe $15 \%$. Nilai tertinggi adalah pada abon nangka muda dengan proporsi $100 \%$ nangka muda. 


\section{Uji organoleptik tingkat kesukaan aroma}

Tabel 9. Pengaruh jenis tempe terhadap aroma

\begin{tabular}{cc}
\hline Jenis Tempe & Kesukaan aroma \\
\hline Tempe Gembos & $3,846^{\mathrm{a}}$ \\
Tempe Kedelai & $4,271^{\mathrm{b}}$
\end{tabular}

Ket : Angka yang ditulis dengan huruf yang sama berarti tidak berbeda nyata

Nilai kesukaan tertinggi terhadap aroma adalah dengan adanya perlakuan penambahan tempe kedelai dengan nilai 4,271, sedangkan nilai kesukaan aroma terendah pada abon nangka muda adalah dengan perlakuan penambahan jenis tempe yaitu dengan penambahan tempe gembos dengan nilai 3,846. Hal ini menunjukkan bahwa semakin banyak penambahan tempe gembus yang digunakan maka dapat memberikan aroma khas tempe gembus yang semakin kuat dan tidak banyak disukai oleh panelis (Manurung, 2009).

Tabel 10. Pengaruh proporsi terhadap kesukaan aroma

\begin{tabular}{cc}
\hline $\begin{array}{c}\text { Proporsi tempe : } \\
\text { Nangka muda }\end{array}$ & $\begin{array}{c}\text { Kesukaan pada } \\
\text { aroma }\end{array}$ \\
\hline $15 \%: 85 \%$ & $3,87^{\mathrm{a}}$ \\
$25 \%: 75 \%$ & $3,98^{\mathrm{ab}}$ \\
$35 \%: 65 \%$ & $4,27^{\mathrm{b}}$ \\
$0: 100 \%$ & $4,12^{\mathrm{ab}}$ \\
\hline
\end{tabular}

Ket : Angka yang ditulis dengan huruf yang sama berarti tidak berbeda nyata

Menurut Winarno (2008) dalam Aida et al. (2014) aroma makanan umumnya menentukan kelezatan bahan makanan dan banyak berhubungan dengan indra penciuman. Abon nangka muda dengan proporsi $15 \%$ menunjukkan sangat berbeda nyata dengan abon nangka muda dengan menggunakan proporsi tempe $35 \%$, sedangkan abon nangka muda dengan proporsi $100 \%$ menunjukkan tidak berbeda nyata dengan proporsi $15 \%$, 25\% dan $35 \%$. Nilai tertinggi kesukaan aroma pada abon nangka muda adalah pada proporsi $35 \%$ tempe dengan skor 4,27. Hal ini menunjukkan bahwa dengan adanya penambahan tempe aroma yang dihasilkan sangat banyak disukai oleh panelis.

\section{Uji organoleptik tingkat kesukaan kesukaan keseluruhan}

Tabel 11. Pengaruh Jenis Tempe terhadap kesukaan keseluruhan

\begin{tabular}{cc}
\hline Jenis Tempe & $\begin{array}{c}\text { Kesukaan } \\
\text { keseluruhan }\end{array}$ \\
\hline Tempe Gembos & $3,921^{\mathrm{a}}$ \\
Tempe Kedelai & $4,167^{\mathrm{b}}$ \\
\hline
\end{tabular}

Ket : Angka yang ditulis dengan huruf yang sama berarti tidak berbeda nyata

Nilai kesukaan tertinggi terhadap kesukaan keseluruhan adalah tanpa adanya perlakuan penambahan tempe kedelai dengan nilai 4,167, sedangkan nilai kesukaan terendah pada abon nangka muda adalah dengan perlakuan penambahan jenis tempe yaitu dengan penambahan tempe gembos dengan nilai 3,921. Abon nangka muda dengan penambahan jenis tempe kedelai menunjukkan adanya perbedaan nyata terhadap abon nangka muda dengan adanya penambahan tempe gembus. Penambahan tempe gembus pada abon nangka muda memberikan kesan yang tidak terlalu banyak disukai oleh panelis.

Tabel 12. Pengaruh proporsi terhadap kesukaan keseluruhan

\begin{tabular}{cc}
\hline $\begin{array}{c}\text { Proporsi tempe : } \\
\text { Nangka muda }\end{array}$ & $\begin{array}{c}\text { Kesukaan pada } \\
\text { kesukaan keseluruhan }\end{array}$ \\
\hline $15 \%: 85 \%$ & $3,70^{\mathrm{a}}$ \\
$25 \%: 75 \%$ & $4,05^{\mathrm{b}}$ \\
$35 \%: 65 \%$ & $4,09^{\mathrm{b}}$ \\
$0: 100 \%$ & $4,33^{\mathrm{b}}$ \\
\hline
\end{tabular}

Ket : Angka yang ditulis dengan huruf yang sama berarti tidak berbeda nyata

Abon nangka muda dengan proporsi $15 \%$ menunjukkan sangat berbeda nyata dengan abon nangka muda yang menggunakan proporsi $25 \%, 35 \%$ dan $100 \%$, sedangkan abon nangka muda dengan proporsi $25 \%$ menunjukkan tidak berbeda nyata dengan abon nangka muda yang menggunakan proporsi $35 \%$ dan $100 \%$. Nilai tertinggi kesukaan keseluruhan pada proporsi $100 \%$ nangka muda dengan nilai 4,33 . Hal ini menunjukkan bahwa panelis suka produk abon nangka muda tanpa adanya perlakuan penambahan tempe. 


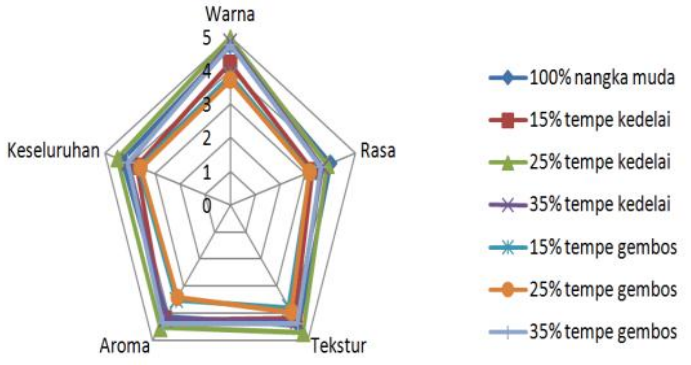

Gambar 1. Grafik kesukaan panelis terhadap abon nangka muda

\section{Parameter Warna}

Pengujian warna pada abon nangka muda menggunakan alat color reader, dengan cara mengetahui nilai $\mathrm{L}^{*}, \mathrm{a}^{*}, \mathrm{~b}^{*}$. Menurut Pomeranz dan Meloans (1994) dalam Satriyanto (2012) Nilai L menyatakan tingkat gelap dan terang dengan standar nilai 0-100, nilai 0 menyatakan bahwa kecenderungan warna hitam atau gelap, sedangkan nilai 100 menunjukkan warna yang dihasilkan terang atau putih, sedangkan nilai $a^{*}$ menunjukkan intensitas warna merah (+) atau hijau (-) dan untuk nilai $\mathrm{b}^{*}$ menunjukkan intensitas warna kuning (+) atau biru (-).

Tabel 13. Pengaruh Jenis Tempe terhadap warna nilai $\mathrm{L}^{*}$

\begin{tabular}{cc}
\hline Jenis Tempe & Warna pada $\mathrm{L}^{*}$ \\
\hline Tempe Gembos & $17,362^{\mathrm{a}}$ \\
Tempe Kedelai & $18,412^{\mathrm{b}}$ \\
\hline
\end{tabular}

Ket : Angka yang ditulis dengan huruf yang sama berarti tidak berbeda nyata

Tingkat kecerahan abon nangka muda dengan adanya penambahan tempe gembus menunjukkan adanya beda nyata dengan abon nangka muda dengan adanya penambahan tempe kedelai. Hal ini disebabkan adanya reaksi antara asam amino dan gula sebagai hasil dari aktifitas enzim amylase dalam menghidrolisis karbohidrat ampas tahu dimana pada akhirnya reaksi ini menyebabkan pencoklatan dan mempengaruhi warna (Astuti et al. 2016). Nilai tertinggi terhadap warna $\mathrm{L}^{*}$ pada abon nangka muda adalah pada abon nangka muda dengan perlakuan penambahan jenis tempe kedelai yaitu 18,412 sementara nilai terendah pada abon nangka muda dengan perlakuan penambahan jenis tempe gembos yaitu dengan nilai 17,362 .

Tabel 14. Pengaruh proporsi terhadap warna

\begin{tabular}{cc}
$\mathrm{L}^{*}$ & \\
\hline $\begin{array}{c}\text { Proporsi tempe : } \\
\text { Nangka muda }\end{array}$ & Warna $\mathrm{L}^{*}$ \\
\hline $15 \%: 85 \%$ & $16,900^{\mathrm{a}}$ \\
$25 \%: 75 \%$ & $17,700^{\mathrm{ab}}$ \\
$35 \%: 65 \%$ & $18,025^{\mathrm{ab}}$ \\
$0: 100 \%$ & $18,925^{\mathrm{b}}$ \\
\hline
\end{tabular}

Nilai tertinggi tingkat kecerahan abon nangka muda adalah pada proporsi nangka muda $100 \%$ tanpa adanya penambahan tempe dengan skor 18,925 . Hal ini dapat diketahui bahwa tanpa adanya perlakuan tingkat kecerahan warna pada abon nangka muda semakin terang.

Tabel 15. Pengaruh Jenis Tempe terhadap warna nilai $\mathrm{a}^{*}$

\begin{tabular}{cc}
\hline Jenis Tempe & Warna pada $\mathrm{a}^{*}$ \\
\hline Tempe Gembos & $9,963^{\mathrm{a}}$ \\
Tempe Kedelai & $11,231^{\mathrm{b}}$ \\
\hline
\end{tabular}

Ket : Angka yang ditulis dengan huruf yang sama berarti tidak berbeda nyata

Nilai tertinggi terhadap warna $a^{*}$ pada abon nangka muda adalah pada abon nangka muda dengan perlakuan penambahan jenis tempe kedelai yaitu 11,231 sementara nilai terendah pada abon nangka muda dengan perlakuan penambahan jenis tempe gembos yaitu dengan nilai 9,963 .

Tabel 16. Pengaruh proporsi terhadap warna $a^{*}$

\begin{tabular}{cc}
\hline $\begin{array}{c}\text { Proporsi tempe : } \\
\text { Nangka muda }\end{array}$ & Warna a* \\
\hline $15 \%: 85 \%$ & $9,412^{\mathrm{a}}$ \\
$25 \%: 75 \%$ & $9,625^{\mathrm{a}}$ \\
$35 \%: 65 \%$ & $11,750^{\mathrm{b}}$ \\
$0: 100 \%$ & $11,600^{\mathrm{b}}$ \\
\hline
\end{tabular}

Ket : Angka yang ditulis dengan huruf yang sama berarti tidak berbeda nyata

Nilai warna $a^{*}$ yang tertinggi adalah pada proporsi abon nangka muda dengan adanya penambahan tempe $35 \%$, sedangkan nilai terendah adalah pada abon nangka muda dengan adanya penambahan tempe $15 \%$. 
Tabel 17. Pengaruh Jenis Tempe terhadap warna nilai $b^{*}$

\begin{tabular}{cc}
\hline Jenis Tempe & Warna $^{*}$ \\
\hline Tempe Gembos & $29,206^{\mathrm{a}}$ \\
Tempe Kedelai & $30,438^{\mathrm{b}}$ \\
\hline
\end{tabular}

Ket : Angka yang ditulis dengan huruf yang sama berarti tidak berbeda nyata

Abon nangka muda dengan adanya penambahan jenis tempe kedelai menunjukkan berbeda nyata dengan abon nangka muda dengan adanya penambahan tempe gembus. Nilai tertinggi $b^{*}$ adalah pada abon nangka muda dengan adanya penambahan jenis tempe kedelai dengan skor 30,438 .

\section{Kadar air}

Tabel 18. Pengaruh Jenis Tempe terhadap uji

kadar air

\begin{tabular}{cc}
\hline Jenis Tempe & Kadar air \\
\hline Tempe Gembos & 5,698 \\
Tempe Kedelai & 5,886 \\
\hline Nilai terendah & adalah pada abon
\end{tabular}

nangka muda dengan adanya penambahan tempe gembos yaitu 5,698 hal ini disebabkan abon nangka muda dengan adanya penambahan tempe gembos yang telah dihilangkan airnya lebih cepat kering pada saat dilakukan penggorengan daripada abon nangka muda dengan adanya penambahan tempe kedelai. Menurut SNI abon 01-37071995 kadar air pada abon maksimal 7\%, hal ini menunjukkan bahwa kadar air pada abon nangka muda ini sudah sesuai dengan syarat mutu abon yang tertera.

Tabel 19. Pengaruh proporsi terhadap kadar

\begin{tabular}{cc} 
air & \\
\hline $\begin{array}{c}\text { Proporsi tempe : } \\
\text { Nangka muda }\end{array}$ & Kadar air \\
\hline $15 \%: 85 \%$ & 6,07988 \\
$25 \%: 75 \%$ & 5,54875 \\
$35 \%: 65 \%$ & 5,93175 \\
$0: 100 \%$ & 5,60725
\end{tabular}

Ket : Angka yang ditulis dengan huruf yang sama berarti tidak berbeda nyata

Hasil kadar air abon nangka muda menunjukkan tidak berbeda nyata antara proporsi $15 \%, 25 \%, 35 \%$ serta $100 \%$. Hal ini sejalan dengan penelitian Syafutri dan Lidiasari (2014) bahwa perakuan konsentrasi penambahan tempe tidak berpengaruh nyata terhadap kadar air trtila labu kuning yang dihasilkan, sehingga penambahan tepung tempe yang berbeda memiiki pengaruh yang sama terhadap kadar air tortilla abu kuning yang dihasilkan.

\section{Hasil Kandungan Protein menggunakan Kjeldahl}

Tujuan analisa protein dalam makanan adalah untuk menera jumlah kandungan protein dalam bahan makanan dengan menentukan tingkat kualitas protein dipandang dari sudut gizi; dan menelaah protein sebagai salah satu bahan kimia (Sudarmadji et al. 2007).

Tabel 20. Hasil uji protein abon nangka muda

\begin{tabular}{ccc}
\hline $\begin{array}{c}\text { Jenis } \\
\text { tempe }\end{array}$ & $\begin{array}{c}\text { Proporsi } \\
\text { Nangka } \\
\text { muda }\end{array}$ & $\begin{array}{c}\text { Protein } \\
(\%)\end{array}$ \\
\hline Tempe & $15 \%: 85 \%$ & 17,51 \\
Kedelai & $25 \%: 75 \%$ & 19,261 \\
& $35 \%: 65 \%$ & 39,3975 \\
Tempe & $15 \%: 85 \%$ & 4,3775 \\
gembos & $25 \%: 75 \%$ & 11,3815 \\
& $35 \%: 65 \%$ & 14,8835 \\
Tanpa & $0: 100 \%$ & 4,3775 \\
tempe & &
\end{tabular}

\begin{tabular}{lrr}
\hline Menurut Aminah & $(2000)$ \\
penambahan tepung tempe dapat
\end{tabular} meningkatkan protein pada produk tiwul dari protein tiwul 2,88\% dengan adanya penambahan tepung tempe dapat meningkat menjadi $16,28 \%$. Hal ini diungkapkan bahwa karena bahan baku tempe memiliki kandungan protein yang lebih tinggi daripada tepung singkong. Abon nangka muda dengan adanya penambahan tempe gembus juga dapat mengalami peningkatan kandungan protein, hal ini dikarenakan tempe gembus juga masih terdapat kandungan proteinnya. Menurut Manurung (2009) dalam pembuatan cookies dengan adanya penambahan tempe gembus dapat meningkatkan kandungan protein cookies tersebut. Cookies tanpa adanya penambahan tempe gembus kandungan proteinnya adalah $6,74 \%$, dengan adanya 
penambahan tempe gembus dapat naik menjadi $12,30 \%$.

\section{KESIMPULAN}

Proporsi tempe yang tepat dalam pembuatan abon nangka muda adalah pada proporsi $25 \%$ tempe dari segi fisik sensoris (warna, rasa, tekstur, aroma dan kesukaan keseluruhan), dari segi kandungan gizi abon nangka muda dengan penambahan tempe $35 \%$ protein yang dihasikan lebih tinggi. Jenis tempe yang tepat untuk digunakan dalam pembuatan abon adalah jenis tempe kedelai

\section{DAFTAR PUSTAKA}

Aida, Y,ChF Mamuaja, AT Agustin. 2014. Pemanfaatan Jantung Pisang (Musa paradisiacal) Dengan Penambahan Daging Ikan Layang (Decapterus sp) Pada Pembuatan Abon. Jurnal Ilmu dan Teknologi Pangan. Vol. 2. No. 1, hal 20 $-26$

Anita SMI. 2011. Pemanfaatan Keluwih (Artocarpus communis) Dalam Pembuatan Abon Nabati Dengan Subtitusi Jamur Tiram (Pleurotus Oestreatus). [Skripsi yang tidak dipublikasikan Universitas Katholik Soegijapranata Semarang]

Aminah, S. 2000. Pengaruh Penambahan Tepung Tempe Terhadap Protein, Sifat Fisik dan Organoleptik Tiwul Instan. Jurnal Litbang Universitas Muhammadiyah Semarang

Anggorowati DA, Harimbi S, Annastasiya, BPP. 2012. Peningkatan Kandungan
Protein Abon Nangka Muda. Jurnal Teknik Kimia. Vol.7.No.1, hal 19-20

Astuti FA, Agustin KW. 2016. Pengaruh Lama Fermentasi Kecap Ampas Tahu Terhadap Kualitas Fisik, Kimia dan Organoleptik. Jurnal Pangan dan Agroindustri.Vol.4 No.1 Hal.72-93

Honestin T. 2007. Karakteristik Sifat Fisiokimia Tepung Ubi Jalar (Ipomoea batatas). [Skripsi yang tidak dipublikasikan. Institut Pertanian Bogor]

Koswara S. 2009. Teknologi Pengolahan Kedelai (Teori dan Praktek). Ebook Pangan.com

Manurung SI, Hendra L, CC Nurwitri. 2009. Pemanfaatan Tepung Tempe Gembus Dalam Pembuatan Cookies. Jurnal Ilmu dan Teknologi Pangan. Vol.7.No.1 hal $64-85$

Satriyanto B, Simon B, Widjanarko, Yunianta (2012). Stabilitas Warna Ekstrak Buah Merah (Pandanus conoideus) Terhadap Pemanasan Sebagai Sumber Potensial Pigmen Alami. Jurnal Teknologi Pertanian. Vol.13.No.3, Hal 157-168

Sudarmadji S, B Haryono, dan Suhardi. 2007. Prosedur Analisa untuk Bahan Makanan dan Pertanian. Liberty. Yogyakarta

Syafutri MI dan Lidiasari E. 2014. Pengaruh Konsentrasi Penambahan Tepung Tempe Terhadap Karakteristik Tortilla Labu kuning. Jurnal Teknologi dan Hasil Pertanian. Vol. 19. No. 2, hal 289 - 296 